\title{
Recent advances in managing overactive bladder [version 1;
}

\section{peer review: 3 approved]}

\section{George Araklitis, Georgina Baines (iD), Ana Sofia da Silva, Dudley Robinson, Linda Cardozo}

Department of Urogynaecology, King's College Hospital, London, UK

V1 First published: 11 Sep 2020, 9(Faculty Rev):1125

https://doi.org/10.12688/f1000research.26607.1

Latest published: 11 Sep 2020, 9(Faculty Rev):1125

https://doi.org/10.12688/f1000research.26607.1

\section{Abstract}

Overactive bladder syndrome (OAB) is defined as urinary urgency, usually accompanied by frequency and nocturia, with or without urgency incontinence, in the absence of urinary tract infection or other obvious pathology. In this review, we focus on recent advances in the management of OAB. We examine the evidence on the effect of anticholinergic load on OAB patients. Advances in medical treatment include a new beta-3 agonist, vibegron, which is thought to have fewer drug interactions than mirabegron. Treatment of genitourinary syndrome of the menopause with oestrogens and ospemifene have also shown promise for OAB. Botulinum toxin has been shown to be an effective treatment option. We discuss the new implantable neuromodulators that are on the market as well as selective bladder denervation and laser technology.

Keywords

Advances, overactive bladder, OAB, treatment

\section{Open Peer Review}

Approval Status

1

2

3

version 1

11 Sep 2020

Faculty Reviews are review articles written by the prestigious Members of Faculty Opinions. The articles are commissioned and peer reviewed before publication to ensure that the final, published version is comprehensive and accessible. The reviewers who approved the final version are listed with their names and affiliations.

\section{Stephen Radley, Sheffield Teaching Hospitals, Sheffield, UK \\ 2. Pierluigi Benedetti Panici, University of Rome "Sapienza," Umberto I Hospital, Rome, Italy \\ Violante Di Donato, University of Rome "Sapienza," Umberto I Hospital, Rome, Italy \\ 3. Jennifer Anger, Cedars-Sinai Medical Center, Los Angeles, USA}

Any comments on the article can be found at the end of the article. 
Corresponding author: George Araklitis (george.araklitis@nhs.net)

Author roles: Araklitis G: Project Administration, Writing - Original Draft Preparation, Writing - Review \& Editing; Baines G: Writing Review \& Editing; da Silva AS: Writing - Review \& Editing; Robinson D: Conceptualization, Supervision; Cardozo L: Conceptualization, Project Administration, Supervision

Competing interests: No competing interests were disclosed.

Grant information: The author(s) declared that no grants were involved in supporting this work.

Copyright: $\odot 2020$ Araklitis G et al. This is an open access article distributed under the terms of the Creative Commons Attribution License, which permits unrestricted use, distribution, and reproduction in any medium, provided the original work is properly cited.

How to cite this article: Araklitis G, Baines G, da Silva AS et al. Recent advances in managing overactive bladder [version 1; peer review: 3 approved] F1000Research 2020, 9(Faculty Rev):1125 https://doi.org/10.12688/f1000research.26607.1

First published: 11 Sep 2020, 9(Faculty Rev):1125 https://doi.org/10.12688/f1000research.26607.1 


\section{Introduction}

Overactive bladder syndrome $(\mathrm{OAB})$ is defined as urinary urgency, usually accompanied by frequency and nocturia, with or without urgency incontinence, in the absence of urinary tract infection or other obvious pathology ${ }^{1}$. The prevalence quoted in studies varies between 1 and $38.8 \%{ }^{2}$. OAB is projected to cost the United States $\$ 82.6$ billion in $2020^{3}$. It can have a negative impact on health-related quality of life and work productivity ${ }^{4}$. Those with bothersome symptoms have higher levels of anxiety and depression ${ }^{4}$. Treatment of OAB includes fluid management, behaviour modification, drug therapy, neuromodulation, and, rarely, surgery. In this review, we focus on recent advances in managing $\mathrm{OAB}$.

\section{Anticholinergic load}

Anticholinergic load is the cumulative effect of taking medication with anticholinergic properties ${ }^{5}$. Many elderly people take numerous medications for various chronic medical conditions, including urinary incontinence, that exert anticholinergic properties $^{5}$. A high anticholinergic load can lead to physical and cognitive impairment in older adults ${ }^{6}$.

An observational retrospective cohort study of 113,311 patients aged over 65 years investigated falls, fractures, and mortality in those taking anticholinergics for $\mathrm{OAB}$ compared to those unexposed to anticholinergics ${ }^{7}$. There was a 1.28 -fold increased risk of falls and fractures in individuals taking anticholinergics compared to controls. Past exposure to anticholinergics for $\mathrm{OAB}$ resulted in an increased risk of 1.14 for falls and fractures compared to controls.

A UK case controlled study of 40,770 adults aged over 65 years from GP data investigated the association between anticholinergics and dementia ${ }^{8}$. Drugs used for OAB were significantly associated with dementia. When the drug was used 4-10 years, 10-15 years, and 15-20 years prior to dementia diagnosis, there were odds ratios (ORs) of $1.23,1.22$, and 1.27 ( $P<0.01)$, respectively. The drugs predominantly used were oxybutynin and tolterodine, which are both older, non-selective, generic medications used to treat $\mathrm{OAB}$.

A US observational study investigated 350 patients aged 65 years or older over 3.2 years 9 . Use of anticholinergic medication was associated with an increased risk of transition from normal cognition to mild impairment (OR 1.15, $P=0.03$ ). A prospective cohort study of 3,434 patients using anticholinergics found that $23 \%$ developed dementia over a mean of 7.3 years ${ }^{10}$. Former users of these drugs had similar risks compared to recent or continued use. Using oxybutynin for over 3 years had the greatest risk of dementia.

A systematic review found 15 out of 27 studies showed a positive correlation between anticholinergic load and mortality ${ }^{6}$. Ten studies found no correlation, and two studies showed mixed results, which may be related to follow up and the quality of the studies. The studies that showed a positive correlation were mainly of high quality.
With these effects in mind, care should be taken when prescribing $\mathrm{OAB}$ medication for older adults. Management of these patients should address mobility, functional impairment, lifestyle modification, urgency suppression, bladder retraining, patient and caregiver expectations, and life expectancy ${ }^{11}$. Despite this, drug therapy may be needed if incontinence does not improve with these supportive measures. Trospium chloride is a quaternary amine anticholinergic, compared to the others, which are tertiary amines. This means trospium chloride is theoretically less likely to cross the blood-brain barrier, and this reduces central nervous system side effects ${ }^{12}$. A randomised double-blind placebo-controlled trial of women aged over 50 years with OAB were treated with placebo or trospium chloride ${ }^{13}$. There was no significant difference in scores of cognitive tests between placebo and treatment at week 4 .

Alternatively, mirabegron could be used as a treatment in this population. A phase IV study found that mirabegron improved symptoms of $\mathrm{OAB}$ in the elderly, with safety and tolerability consistent with known mirabegron safety profile ${ }^{14}$. A subanalysis of the BESIDE study in those aged over 65 years, which investigated the combination of solifenacin and mirabegron, found no difference between solifenacin $5 \mathrm{mg}$ plus mirabegron $50 \mathrm{mg}$ compared to solifenacin $10 \mathrm{mg}^{15}$. The authors argue that combination therapy may be better for the elderly rather than solifenacin $10 \mathrm{mg}$, as the latter may increase the anticholinergic load. Another study found that there was no significant change in the Montreal Cognitive Assessment from baseline to week 12 in elderly patients using mirabegron ${ }^{16}$.

\section{Advances in medical treatment}

\section{Beta-3 agonists}

Two classes of drug therapy are employed in the management of OAB. There have been no recent advances in anticholinergic medication, which is the main pharmacological treatment for OAB. Mirabegron, a beta- 3 agonist, has been used as an alternative to anticholinergics since 2013 ${ }^{17}$. In September 2018, vibegron, a selective beta-3 adrenoreceptor agonist, was approved in Japan for the treatment of $\mathrm{OAB}^{18}$. It is unlikely to be metabolised by CYP3A4 or CYP2D6 ${ }^{19}$; therefore, there is a low risk of drug interactions. Mirabegron inhibits CYP2D6 and is therefore a source of drug interactions ${ }^{20}$.

A phase III multicentre prospective study investigated vibegron in an $\mathrm{OAB}$ population over 12 months $^{21}$. There were significant improvements in $\mathrm{OAB}$ symptoms from baseline compared to week 4 and continued improvement until week 52. There was also a significant improvement in all King's Health Questionnaire (KHQ) score domains, except for general health perception. The KHQ is a disease-specific quality of life questionnaire for patients with urinary incontinence.

A multicentre, randomised, four-arm, parallel-group, placebocontrolled phase III study of patients with $\mathrm{OAB}$ was performed on 1,230 patients ${ }^{22}$. There were significant improvements in $\mathrm{OAB}$ symptoms with vibegron over placebo. There were also improvements in all KHQ score domains, except for general 
health perception and personal relationships. Adverse events were similar amongst placebo, vibegron, and imidafenacin (an anticholinergic) groups. There were no changes in vital signs.

\section{Phosphodiesterase type 5 inhibitors}

Phosphodiesterase type 5 inhibitors (PDE5Is) are used to treat erectile dysfunction. A randomised, double-blind, placebo-controlled trial investigated the efficacy and safety of daily low-dose tadalafil for 96 female patients with $\mathrm{OAB}^{23}$. There were significant improvements in the overactive bladder symptom score and Indevus Urgency Severity Scale. There were significant reductions in $\mathrm{OAB}$ symptoms compared with baseline and placebo. There were no reported serious adverse events. It is hypothesised that tadalafil reduces the contraction of the detrusor muscle. Further larger and longer studies are needed to confirm these results. At present, these medications are not considered first-line therapy for OAB.

\section{Genitourinary syndrome of menopause treatment for OAB}

Genitourinary syndrome of menopause (GSM) is the new terminology for vulvovaginal atrophy and urinary symptoms, which may occur together or independently ${ }^{24}$. There is evidence to show that oestrogen deficiency may increase the risk of $\mathrm{OAB}^{25}$. A meta-analysis reviewed 10 randomised placebo-controlled trials $^{26}$. It found that oestrogen therapy was superior to placebo for frequency, nocturia, and urgency incontinence. Vaginal oestrogens were better than systemic oestrogens for urinary urgency.

Combination therapy in the form of vaginal oestrogens and anticholinergics may help improve OAB symptoms. One study investigated solifenacin, with or without intra-vaginal promestriene, in 104 postmenopausal women over 12 weeks ${ }^{27}$. Both groups had a significant reduction in frequency, urgency, urgency incontinence episodes, and nocturia but without a significant difference between the groups. The combination group did have a significantly better reduction in OAB symptom score questionnaire $(P=0.016)$ compared to solifenacin alone.

Another study investigated fesoterodine with or without vaginal premarin ${ }^{28}$. Both groups had improvements in OAB symptoms. The combination group had better improvement in OAB symptom score questionnaire, $\mathrm{OAB}$ health-related quality of life score, and sexual quality of life questionnaire scores.

Ospemifene is a selective oestrogen receptor modulator that has an oestrogen agonist effect and can be used by those in whom oestrogen therapy may be contraindicated ${ }^{29}$. A study of 105 patients found a significant improvement in frequency, nocturia, urgency, and urgency incontinence ${ }^{29}$. There were also significant improvements in $\mathrm{OAB}$ questionnaire scores. A retrospective review of 46 women using ospemifene for GSM found a significant improvement in frequency, nocturia, urgency, and urgency incontinence ${ }^{30}$.

\section{Onabotulinumtoxin A}

OnabotulinumtoxinA ("botox") helps those with OAB by inhibiting acetylcholine release, leading to bladder detrusor muscle paralysis $^{31}$. A systematic review and meta-analysis has shown significant incontinence-free episodes $(P<0.001)$, reduction in urinary incontinence episodes $(P<0.001)$, and reduction in mean number of micturitions $(P<0.001)^{32}$.

A recent meta-analysis of 19 studies found that doses of $200 \mathrm{U}$ and $300 \mathrm{U}$ were more effective than placebo for the treatment of neurogenic detrusor overactivity, with minimal but manageable side effects ${ }^{33}$. A double-blind, randomised, placebo-controlled trial investigated different doses of botulinum toxin ${ }^{34}$. A dose greater than $150 \mathrm{U}$ had minimal additional improvement in symptoms, with increased risk of urinary retention and need to self-catheterise. The authors recommend using $100 \mathrm{U}$, which they feel balances symptom improvement and safety profile. The National Institute for Health and Care Excellence (NICE), which provides health guidance in the United Kingdom, recommends using $100 \mathrm{U}^{35}$.

A recent study investigated bladder trigone-involved injections against those with trigone-sparing injections ${ }^{36}$. A total of 103 patients received $100 \mathrm{U}$ and were followed up at 6 months. Both groups had a reduction in $\mathrm{OAB}$ outcome measures, but there was no difference between groups. The trigone-involved group had a higher incidence of urinary tract infection and voiding difficulties.

\section{Neuromodulation}

\section{Posterior tibial nerve stimulation}

Posterior tibial nerve stimulation involves the use of electrical impulses and is a form of neuromodulation employed to improve urinary symptoms ${ }^{37}$. This can be in the form of percutaneous tibial nerve stimulation (PTNS), which uses a needle, and transcutaneous tibial nerve stimulation (TTNS), which uses pads. This treatment usually involves weekly 30-minute visits to the hospital for up to 12 weeks. More recently, implantable devices have become available.

The RENOVA iStim ${ }^{\mathrm{TM}}$ is a wirelessly powered implant. The implant is surgically inserted under local anaesthesia. The incision is made $3 \mathrm{~cm}$ superior and $2 \mathrm{~cm}$ posterior to the medial malleolus. The electrode is placed near the tibial nerve and secured with a non-absorbable suture. An external control unit is worn around the ankle to activate the electrodes. This unit is worn six times a week for 30 minutes to activate treatment ${ }^{37,38}$. A study of 15 patients (13 female) showed a significant improvement in frequency, urgency, and urgency incontinence episodes at 3 months ${ }^{38}$. There was also significant improvement in quality of life. Three patients required a week of antibiotics and three required a week of analgesics. One device was explanted for suspected infection, although cultures were negative. None of the patients reported difficulty in operating the device.

A 6-month study evaluated the implant in 36 patients $^{39}$. A total of $71 \%$ of patients experienced clinical success $(>50 \%$ reduction) at 6 months. The number of leaks per day, leak severity, frequency, degree of urgency, and pad changes per day reduced significantly. A total of $28 \%$ of patients with urgency incontinence were dry. There was significant improvement in OAB-q questionnaire scores. Adverse events were noted in $47 \%$ of 
patients; $14 \%$ had pain, $22 \%$ suspected infection, and $8 \%$ wound complications. One patient had the implant removed owing to pain and swelling, but cultures excluded infection. A total of 20 patients from the previous study were enrolled in a 3-year follow up $\operatorname{study}^{40}$. A total of $75 \%$ had a $>50 \%$ improvement in symptoms, with significant improvement in quality of life. The majority of patients were moderately or very satisfied. No adverse events were reported between 6 months and 3 years.

Another implant is the primary battery-powered, nickel-sized and -shaped neuromodulation device called the eCoin ${ }^{\circledR}$ for tibial nerve stimulation to treat refractory urgency urinary incontinence. A study of 46 patients found a significant reduction in urgency incontinence episodes ${ }^{41}$. A total of $72 \%$ had an improvement in symptoms, with $20 \%$ dry at 6 months. One adverse event was recorded secondary to infection, which was successfully treated with intravenous antibiotics. This device is still undergoing FDA clinical trials ${ }^{42}$.

\section{Sacral neuromodulation}

In 1997, the FDA approved sacral neuromodulation (SNM) for the treatment of refractory urgency, urgency urinary incontinence, and frequency ${ }^{43}$. It has been implanted in over 200,000 patients, with success rates between 62 and $90 \%{ }^{43}$. It does carry frequent adverse events, with surgical revision between 3 and $16 \%{ }^{43}$. The device will need to be replaced after the battery runs its lifespan, with replacements occurring on average after 62.5 months ${ }^{44}$. The manufacturer of the InterStim device, Medtronic, recommends that MRI should not be performed in patients with the device ${ }^{45}$. They allow MRI of the head only if the device is turned off and a 1.5-Tesla magnet or lower is used.

Recently, an implantable rechargeable SNM system by Axonics has come on the market. This has addressed the issue of the shorter battery lifespan of the InterStim with a rechargeable lithium ion battery, lasting up to 15 years or longer ${ }^{46}$. With typical use, the battery should last 2 weeks before needing to be recharged. This is done by a wireless charger and takes 1 to 2 hours $^{47}$. It was designed so that the implantation procedure was nearly identical to the InterStim ${ }^{47}$. The Axonics SNM is $60 \%$ smaller than the InterStim, with the goal of reducing the risk of discomfort and making it more suitable for those with a lower BMI ${ }^{47}$. It is made of titanium and ceramic rather than just titanium. The ceramic has a ferrite core, which reduces heat generation during charging and allows charging of up to $3 \mathrm{~cm}$ depth ${ }^{46}$. It also relies on a current controlled system rather than the voltage controlled system of the InterStim. Therefore, if tissue resistance increases with time, the voltage will increase automatically to maintain constant current to the nerve, avoiding the need to manually increase the current ${ }^{47}$. The Axonics rechargeable neurostimulator is safe for MRI with 1.5-Telsa full body and 3-Tesla head $\mathrm{MRI}^{48}$.

The rechargeable device is thought to save $\$ 27,121$ per patient over 15 years $^{49}$. It was projected it could save the United States healthcare system up to $\$ 12$ billion. NICE recommends the use of the Axonics SNM. It estimates cost savings of $£ 6,200$ per person, which begin 6 years after implantation ${ }^{50}$. The expected publication of the NICE guideline was June 2020 .

A prospective, multicentre study implanted 51 patients suffering from $\mathrm{OAB}$ with the rechargeable SNM device ${ }^{51}$. At 12 months, 96\% experienced a reduction in urinary incontinence $(P<0.001)$ and $71 \%$ had a significant reduction in urinary frequency $(P<0.001)$. There was a significant improvement in quality of life $(P<0.001)$. At 1 year, $77 \%$ of all subjects were very or moderately satisfied and $79 \%$ would recommend the treatment to a friend. The duration of charging was acceptable to $98 \%$, with $83 \%$ finding it easy to charge. Adverse events occurred in $25 \%$ of subjects. The most common was undesirable or uncomfortable stimulation, which was resolved with reprogramming. Pain at the implant site occurred in $2 \%$. There was one incident of lead migration. One subject had an infection requiring explantation 3 weeks later. Two other patients had their device removed because of lack of efficacy.

If SNM fails, treatment of refractory $\mathrm{OAB}$ can be very difficult. A study of 52 patients in whom SNM did not work found botulinum toxin to be a successful treatment in $27 \%$ of cases $^{52}$. A recent study assessing the cost effectiveness of SNM or $200 \mathrm{U}$ botulinum toxin for the management of refractory OAB found the former to incur higher $\operatorname{costs}^{53}$. At 2 years, SNM cost $\$ 35,680$ compared to $\$ 7,460$ for botulinum toxin and at 5 years cost $\$ 36,550$ compared to $\$ 12,020$. There was no difference in reduction in urgency incontinence episodes between the treatments at 2 years.

\section{Selective bladder denervation}

Selective bladder denervation (SBD) is a procedure that involves radiofrequency ablation of the sub-trigone area of the bladder, which contains afferent sensory nerves ${ }^{54}$. The device is applied to the trigone under cystoscopic guidance. The thermal delivery probe is placed along the left border of the trigone $5 \mathrm{~mm}$ below the ureteric orifice. The electrodes are then advanced $3 \mathrm{~mm}$ into the urothelium and ablation begins. This is repeated on the right border of the trigone and again in numerous points in between these two borders.

A total of 63 patients with refractory $\mathrm{OAB}$ underwent this treatment ${ }^{54}$. At 12 weeks, there were significant reductions in frequency, urgency episodes, and urgency incontinence episodes. There was a significant improvement in $\mathrm{OAB}$ questionnaire scores and quality of life $(P<0.01)$. Ablation for 60 seconds had significantly greater improvement in urgency incontinence episodes and quality of life scores than ablation for 10 seconds, with no significant difference in post void residuals. Post procedure pain was minimal over 5 days. One woman had a serious adverse event of obstruction of the left ureter, leading to hydronephrosis and pyelonephritis 8 days later. Lower urinary tract infection occurred in $9.5 \%$. No patients had urinary retention requiring catheterisation.

This study was performed under sedation or a general anaesthetic. The authors are planning to study the use of local anaesthesia. 
This human feasibility study was also non-randomised, which introduces bias. The results and safety profile are promising, but larger controlled studies with longer follow up are needed.

\section{Laser treatment}

Light amplification by stimulated emission of radiation (laser) was first described by Einstein in $1917^{55}$. It is used for different medical reasons. The two most commonly used lasers are microablative fractional $\mathrm{CO}_{2}$ laser (SmartXide ${ }^{2}-\mathrm{V}^{2} \mathrm{LR}$, MonaLisa Touch; DEKA, Florence, Italy) and non-ablative photothermal erbium:YAG (Er:YAG) laser (Fotona Smooth XS; Fotona, Ljubljana Slovenia) $)^{55}$. The laser causes thermomodulation by heating and (in the case of the $\mathrm{CO}_{2}$ laser) ablating columns of tissue ${ }^{55}$.

A prospective observational pilot study ${ }^{56}$ enrolled 30 postmenopausal women with vulvovaginal atrophy and OAB. They were treated with $\mathrm{CO}_{2}$ laser, with three treatments 30 days apart. The procedure was performed in an ambulatory setting without analgesia or anaesthetic. There were significant improvements in bladder diary values $(P<0.0001)$, number of urgency episodes $(P<0.0001)$, urgency incontinence episodes $(P=0.006)$, and $\mathrm{OAB}$ questionnaire scores $(P<0.0001)$. There were no adverse events.

Another study recruited 150 postmenopausal patients to Er:YAG laser (three treatments, 1 month apart), an anticholinergic (fesoterodine), or mirabegron ${ }^{57}$. There were significant improvements in OAB symptom scores in all three groups $(P<0.001)$, but only the laser group reported improvement in vaginal health index scale at 12 months. There were no adverse events with the laser. A further study of 30 women completed two sessions of Er:YAG laser treatment ${ }^{58}$. There were significant improvements in $\mathrm{OAB}$ symptom scores at 3 months $(P=0.027)$ but not at 12 months $(P=0.576)$. No major adverse events occurred. Most described mild pain and few had vaginal discharge or spotting for several days.

At present, there is little evidence to support the use of laser for OAB. Further larger controlled studies are needed.

\section{Conclusion}

This article highlights the recent advances in the management of OAB. When prescribing for older adults, care is needed because of the risks associated with a high anticholinergic load. Alternative treatments may be needed, including mirabegron, which does not add to the load. Vibegron is a promising beta-3 agonist that has potentially fewer drug interactions but is licensed only in Japan. Further studies are needed for PDE5Is. Botulinum toxin has been shown to be a good treatment option. There have been promising developments in implantable devices for both PTNS and SNM, with the latter rechargeable device being implemented soon in the UK. SBD and laser are new technologies that show improvements in $\mathrm{OAB}$, but further studies are needed before they can be recommended as treatments.
1. Haylen BT, de Ridder D, Freeman RM, et al.: An International Urogynecological Association (IUGA)/International Continence Society (ICS) joint report on the terminology for female pelvic floor dysfunction. Neurourol Urodyn. 2010; 29(1): 4-20.

PubMed Abstract | Publisher Full Text | Faculty Opinions Recommendation

2. Milsom I, Coyne KS, Nicholson S, et al.: Global Prevalence and Economic Burden of Urgency Urinary Incontinence: A Systematic Review. Eur Urol. 2014; 65(1): 79-95

PubMed Abstract | Publisher Full Text | Faculty Opinions Recommendation

3. Coyne KS, Wein A, Nicholson S, et al.: Economic burden of urgency urinary incontinence in the United States: a systematic review. J Manag Care Pharm. 2014; 20(2): 130-40.

PubMed Abstract | Publisher Full Text

4. Coyne KS, Sexton CC, Kopp ZS, et al.: The impact of overactive bladder on mental health, work productivity and health-related quality of life in the UK and Sweden: results from EpiLUTS. BJU Int. 2011; 108(9): 1459-71. PubMed Abstract | Publisher Full Text

5. Tune LE: Anticholinergic effects of medication in elderly patients. J Clin Psychiatry. 2001; 62 Suppl 21: 11-4. PubMed Abstract

6. Ali S, Peterson GM, Bereznicki LR, et al.: Association between anticholinergic drug burden and mortality in older people: a systematic review. Eur J Clin Pharmacol. 2020; 76(3): 319-35. PubMed Abstract | Publisher Full Text | Faculty Opinions Recommendation

7. Suehs BT, Caplan EO, Hayden J, et al.: The Relationship Between Anticholinergic Exposure and Falls, Fractures, and Mortality in Patients with Overactive Bladder. Drugs Aging. 2019; 36(10): 957-67.

PubMed Abstract | Publisher Full Text | Faculty Opinions Recommendation

8. Richardson K, Fox C, Maidment I, et al.: Anticholinergic drugs and risk of dementia: case-control study. BMJ. 2018; 361: k1315.

PubMed Abstract | Publisher Full Text | Free Full Text | Faculty Opinions Recommendation

9. Campbell NL, Lane KA, Gao S, et al.: Anticholinergics Influence Transition from Normal Cognition to Mild Cognitive Impairment in Older Adults in Primary Care. Pharmacotherapy. 2018; 38(5): 511-9.

PubMed Abstract | Publisher Full Text | Free Full Text |

Faculty Opinions Recommendation

10. Gray SL, Anderson ML, Dublin S, et al.: Cumulative use of strong anticholinergics and incident dementia: a prospective cohort study. JAMA Intern Med. 2015; 175(3): 401-7.

PubMed Abstract | Publisher Full Text | Free Full Text | Faculty Opinions Recommendation

11. W Wagg A: Anticholinergics for Overactive Bladder in Frail and Medically Complex Older People: The Case For. Drugs Aging. 2018; 35(9): 777-80. PubMed Abstract | Publisher Full Text | Faculty Opinions Recommendation

12. Pratt TS, Suskind AM: Management of Overactive Bladder in Older Women. Curr Urol Rep. 2018; 19(11): 92. PubMed Abstract | Publisher Full Text | Free Full Text Faculty Opinions Recommendation

13. Geller EJ, Dumond JB, Bowling JM, et al.: Effect of Trospium Chloride on Cognitive Function in Women Aged 50 and Older: A Randomized Trial. Female Pelvic Med Reconstr Surg. 2017; 23(2): 118-23. PubMed Abstract | Publisher Full Text

14. W Wagg A, Staskin D, Engel E, et al.: Efficacy, safety, and tolerability of mirabegron in patients aged $\geq 65 \mathrm{yr}$ with overactive bladder wet: a phas IV, double-blind, randomised, placebo-controlled study (PILLAR). Eur Urol. 2020; 77(2): 211-20.

PubMed Abstract | Publisher Full Text | Faculty Opinions Recommendation

15. Gibson W, MacDiarmid S, Huang M, et al.: Treating Overactive Bladder in 
Older Patients with a Combination of Mirabegron and Solifenacin: A Prespecified Analysis from the BESIDE Study. Eur Urol Focus. 2017; 3(6): 629-38

PubMed Abstract | Publisher Full Text

16. Griebling TL, Campbell NL, Mangel J, et al.: Effect of mirabegron on cognitive function in elderly patients with overactive bladder: MoCA results from a phase 4 randomized, placebo-controlled study (PILLAR). BMC Geriatr. 2020; 20(1): 109.

PubMed Abstract | Publisher Full Text | Free Full Text |

Faculty Opinions Recommendation

17. TA290: Mirabegron for treating symptoms of overactive bladder. NICE guidance. 2013.

Reference Source

18. Keam SJ: Vibegron: First Global Approval. Drugs. 2018; 78(17): 1835-9. PubMed Abstract | Publisher Full Text | Faculty Opinions Recommendation

19. Edmondson SD, Zhu C, Kar NF, et al.: Discovery of Vibegron: A Potent and Selective $\beta 3$ Adrenergic Receptor Agonist for the Treatment of Overactive Bladder. J Med Chem. 2016; 59(2): 609-23.

PubMed Abstract | Publisher Full Text

20. Bragg R, Hebel D, Vouri SM, et al.: Mirabegron: a Beta-3 agonist for overactive bladder. Consult Pharm. 2014; 29(12): 823-37. PubMed Abstract | Publisher Full Text | Free Full Text

21. Yoshida $\mathrm{M}$, Kakizaki $\mathrm{H}$, Takahashi $\mathrm{S}$, et al.: Long-term safety and efficacy of the novel $\beta_{3}$-adrenoreceptor agonist vibegron in Japanese patients with overactive bladder: A phase III prospective study. Int J Urol. 2018; 25(7): $668-75$.

PubMed Abstract | Publisher Full Text | Faculty Opinions Recommendation

22. Yoshida M, Takeda M, Gotoh M, et al.: Vibegron, a Novel Potent and Selective $\beta_{3}$-Adrenoreceptor Agonist, for the Treatment of Patients with Overactive Bladder: A Randomized, Double-blind, Placebo-controlled Phase 3 Study. Eur Urol. 2018; 73(5): 783-90.

PubMed Abstract | Publisher Full Text | Faculty Opinions Recommendation

23. Chen H, Wang F, Yu Z, et al.: Efficacy of Daily Low-dose Tadalafil for Treating Overactive Bladder: Results of a Randomized, Double-blind, Placebocontrolled Trial. Urology. 2017; 100: 59-64.

PubMed Abstract | Publisher Full Text

24. Portman DJ, Gass MLS, Vulvovaginal Atrophy Terminology Consensus Conference Panel: Genitourinary syndrome of menopause: new terminology for vulvovaginal atrophy from the International Society for the Study of Women's Sexual Health and The North American Menopause Society. Climacteric. 2014; 17(5): 557-63. PubMed Abstract | Publisher Full Text

25. Cheng $\mathrm{CL}$, Li JR, $\mathrm{Lin} \mathrm{CH}$, et al:: Positive association of female overactive bladder symptoms and estrogen deprivation: A nationwide populationbased cohort study in Taiwan. Medicine (Baltimore). 2016; 95(28): e4107. PubMed Abstract | Publisher Full Text | Free Full Text

26. Cardozo L, Lose G, McClish D, et al.: Estrogen treatment for symptoms of an overactive bladder, results of a meta analysis. Int J Urogynaecol. 2001; 12(3): V.

27. Jiang F, Zhu L, Xu T, et al.: Efficacy and safety of solifenacin succinate tablets versus solifenacin succinate tablets with local estrogen for the treatment of overactive bladder in postmenopausal women--a multicenter, randomized, open-label, controlled comparison study. Menopause. 2016; 23(4): 451-7.

PubMed Abstract | Publisher Full Text

28. Chughtai B, Forde JC, Buck J, et al: The concomitant use of fesoterodine and topical vaginal estrogen in the management of overactive bladder and sexual dysfunction in postmenopausal women. Post Reprod Health. 2016; 22(1): 34-40.

PubMed Abstract | Publisher Full Text

29. Schiavi MC, Sciuga V, Giannini A, et al.: Overactive bladder syndrome treatment with ospemifene in menopausal patients with vulvovaginal atrophy: improvement of sexuality? Gynecol Endocrinol. 2018; 34(8): 666-9. PubMed Abstract | Publisher Full Text | Faculty Opinions Recommendation

30. Schiavi MC, Zullo MA, Faiano P, et al.: Retrospective analysis in $\mathbf{4 6}$ women with vulvovaginal atrophy treated with ospemifene for 12 weeks: improvement in overactive bladder symptoms. Gynecol Endocrinol. 2017: 33(12): 942-5.

PubMed Abstract | Publisher Full Text

31. Duthie J, Wilson DI, Herbison GP, et al.: Botulinum toxin injections for adults with overactive bladder syndrome. Cochrane Database Syst Rev. 2011; (3): CD005493.

PubMed Abstract | Publisher Full Text

32. Cui $Y$, Zhou $X$, Zong $H$, et al.: The efficacy and safety of onabotulinumtoxinA in treating idiopathic OAB: A systematic review and meta-analysis.

Neurourol Urodyn. 2015; 34(5): 413-9.

PubMed Abstract | Publisher Full Text

33. C Gong QQ, Xu YQ, Xu J, et al: Meta-Analysis of Randomized Controlled Trials Using Botulinum Toxin A at Different Dosages for Urinary Incontinence in Patients With Overactive Bladder. Front Pharmacol. 2020; 10: 1618

PubMed Abstract | Publisher Full Text | Free Full Text

Faculty Opinions Recommendation
34.

, Chapple C, Nitti VW, et al.: Efficacy and safety of onabotulinumtoxinA for idiopathic overactive bladder: a double-blind, placebo controlled, randomized, dose ranging trial. J Urol. 2010; 184(6): 2416-22.

PubMed Abstract | Publisher Full Text | Faculty Opinions Recommendation

35. Urinary incontinence and pelvic organ prolapse in women: management. NICE guideline. 2019

Reference Source

36. El-Hefnawy AS, Elbaset MA, Taha DE, et al.: Trigonal-sparing versus trigonal-involved Botox injection for treatment of idiopathic overactive bladder: A randomized clinical trial. Low Urin Tract Symptoms. 2020. PubMed Abstract | Publisher Full Text | Faculty Opinions Recommendation

37. Bhide AA, Tailor V, Fernando R, et al:: Posterior tibial nerve stimulation for overactive bladder-techniques and efficacy. Int UrogynecolJ. 2020; 31(5): 865-70.

PubMed Abstract | Publisher Full Text | Free Full Text |

Faculty Opinions Recommendation

38. van Breda HMK, Martens FMJ, Tromp J, et al.: A New Implanted Posterior Tibial Nerve Stimulator for the Treatment of Overactive Bladder Syndrome: 3-Month Results of a Novel Therapy at a Single Center. J Urol. 2017; 198(1): 205-10.

PubMed Abstract | Publisher Full Text

39. Heesakkers JPFA, Digesu GA, van Breda J, et al.: A novel leadless, miniature implantable Tibial Nerve Neuromodulation System for the management of overactive bladder complaints. Neurourol Urodyn. 2018; 37(3): 1060-7

PubMed Abstract | Publisher Full Text | Faculty Opinions Recommendation

40. Dmochowski RR, van Kerrebroeck P, Digesu GA, et al.: PD31-02 LONG-TERM RESULTS OF SAFETY, EFFICACY, QUALITY OF LIFE AND SATISFACTION OF PATIENTS TREATED FOR REFRACTORY OAB USING AN IMPLANTABLE TIBIA NEUROSTIMULATION SYSTEM: RENOVA ISTIM ${ }^{\text {TM }}$ SYSTEM. J Urol. 2019; 201: e565-e566.

Publisher Full Text

41. N MacDiarmid S, Staskin DR, Lucente V, et al.: Feasibility of a Fully Implanted, Nickel Sized and Shaped Tibial Nerve Stimulator for the Treatment of Overactive Bladder Syndrome with Urgency Urinary Incontinence. J Urol. 2019; 201(5): 967-72.

PubMed Abstract | Publisher Full Text | Faculty Opinions Recommendation

42. Yamashiro J, de Riese W, de Riese C: New Implantable Tibial Nerve Stimulation Devices: Review of Published Clinical Results in Comparison to Established Neuromodulation Devices. Res Rep Urol. 2019; 11: 351-7. PubMed Abstract | Publisher Full Text | Free Full Text

43. Michalak JR, Kim S, Funk JT, et al.: Sacral Neuromodulation for Overactive Bladder. In Adult and Pediatric Neuromodulation. Springer, Cham. 2018; 25-46.

44. Marcelissen TAT, Leong RK, de Bie RA, et al.: Long-term results of sacral neuromodulation with the tined lead procedure. J Urol. 2010; 184(5): 1997 2000.

PubMed Abstract | Publisher Full Text

45. MRI guidelines for InterStim Therapy Neurostimulation Systems. 1st ed. Medtronic, 2017. Reference Source

46. The Axonics Sacral Neuromodulation System: Product Overview and Technical Deep-Dive. 2016.

47. Cohn JA, Kowalik CG, Kaufman MR, et al.: Evaluation of the axonics modulation technologies sacral neuromodulation system for the treatment of urinary and fecal dysfunction. Expert Rev Med Devices. 2016; 14(1): 3-14. PubMed Abstract | Publisher Full Text

48. https://www.axonics.com/hcp/axonics-system/system-overview

49. Noblett KL, Dmochowski RR, Vasavada SP, et al.: Cost profiles and budget impact of rechargeable versus non-rechargeable sacral neuromodulation devices in the treatment of overactive bladder syndrome. Neurourol Urodyn. 2017; 36(3): 727-33.

PubMed Abstract | Publisher Full Text

50. https://www.nice.org.uk/consultations/633/1/recommendations

51. Dilok B, van Kerrebroeck $P$, de Wachter $S$, et al:: A prospective, multicenter study of a novel, miniaturized rechargeable sacral neuromodulation system: 12-month results from the RELAX-OAB study. Neurourol Urodyn. 2019; 38(2): 689-95

PubMed Abstract | Publisher Full Text | Faculty Opinions Recommendation

52. Baron M, Delcourt C, Pfister C, et al.: Efficacy and tolerance of botulinum toxin injections after sacral nerve stimulation failure for idiopathic overactive bladder. European Urology Supplements. 2018; 17(2): e1356. Publisher Full Text

53. Harvie HS, Amundsen CL, Neuwahl SJ, et al.: Cost-Effectiveness of Sacra Neuromodulation versus OnabotulinumtoxinA for Refractory Urgency Urinary Incontinence: Results of the ROSETTA Randomized Trial. J Urol. 2020; 203(5): 969-77.

PubMed Abstract | Publisher Full Text | Free Full Text |

Faculty Opinions Recommendation 
54. Le Tu M, de Wachter S, Robert M, et al.: Initial clinical experience with selective bladder denervation for refractory overactive bladder. Neurourol Urodyn. 2019; 38(2): 644-52.

PubMed Abstract | Publisher Full Text | Free Full Text | Faculty Opinions Recommendation

55. Robinson $D$, Flint $R$, Veit-Rubin $N$, et al.: Is there enough evidence to justify the use of laser and other thermal therapies in female lower urinary tract dysfunction? Report from the ICI-RS 2019. Neurourol Urodyn. 2020; 39 SuppI 3: S140-S147.

PubMed Abstract | Publisher Full Text

56. Perino A, Cucinella G, Gugliotta G, et al.: Is vaginal fractional $\mathrm{CO} 2$ lase treatment effective in improving overactive bladder symptoms in postmenopausal patients? Preliminary results. Eur Rev Med Pharmacol Sci. 2016;
20(12): 2491-7.

PubMed Abstract

57. Okui N: Efficacy and safety of non-ablative vaginal erbium: YAG laser treatment as a novel surgical treatment for overactive bladder syndrome: comparison with anticholinergics and $\beta$ 3-adrenoceptor agonists. World J Urol. 2019; 37(11): 2459-66.

PubMed Abstract | Publisher Full Text | Free Full Text |

Faculty Opinions Recommendation

58. Lin YH, Hsieh WC, Huang L, et al.: Effect of non-ablative laser treatment on overactive bladder symptoms, urinary incontinence and sexual function in women with urodynamic stress incontinence. Taiwan / Obstet Gynecol. 2017; 56(6): 815-20.

PubMed Abstract | Publisher Full Text 


\section{Open Peer Review}

\section{Current Peer Review Status:}

\section{Editorial Note on the Review Process}

Faculty Reviews are review articles written by the prestigious Members of Faculty Opinions. The articles are commissioned and peer reviewed before publication to ensure that the final, published version is comprehensive and accessible. The reviewers who approved the final version are listed with their names and affiliations.

\section{The reviewers who approved this article are:}

\section{Version 1}

\section{Jennifer Anger}

Division of Urology, Cedars-Sinai Medical Center, Los Angeles, CA, USA

Competing Interests: No competing interests were disclosed.

\section{Pierluigi Benedetti Panici}

Department of Gynecological-Obstetric Sciences and Urological Sciences, University of Rome "Sapienza," Umberto I Hospital, Rome, Italy

\section{Violante Di Donato}

Department of Gynecological-Obstetric Sciences and Urological Sciences, University of Rome "Sapienza," Umberto I Hospital, Rome, Italy

Competing Interests: No competing interests were disclosed.

\section{Stephen Radley}

Department of Urogynaecology, Sheffield Teaching Hospitals, Sheffield, UK

Competing Interests: No competing interests were disclosed. 
The benefits of publishing with F1000Research:

- Your article is published within days, with no editorial bias

- You can publish traditional articles, null/negative results, case reports, data notes and more

- The peer review process is transparent and collaborative

- Your article is indexed in PubMed after passing peer review

- Dedicated customer support at every stage

For pre-submission enquiries, contact research@f1000.com 